\title{
THE PROTECTIVE EFFECT OF ZINGIBER OFFICINALE L. EXTRACT ON KIDNEY TISSUES AND BLOOD FACTORS OF KIDNEY FUNCTIONS AFTER THE DAMAGE CAUSED BY AZATHIOPRINE
}

\author{
Saja Majeed Shareef, Raghad Abdulsalam Khaleel, Zinah Essam Hameed, \\ Khulood Majid Alsaraf
}

The most commonly prescribed medication for autoimmune disorders is Azathioprine (AZA), which negatively affects renal function and tissue structure. The aim of this work was to measure the therapeutic impact of Zingiber officinale L. extract (ZOE) on improving the function and structure of AZA-induced renal damaged tissue.

Methods: 70 rats with a weight range of $200 \pm 10 \mathrm{~g}$ and an age of $95 \pm 5$ days were chosen for this experimental study. The animals were grouped into seven groups of ten, with two groups receiving no treatment (control groups) and five groups receiving $Z O E, A Z A$, “ $A Z A+Z O E$ ", and normal saline. AZA was given intraperitoneally, and $Z O E$ was given by gavage (i.e., nasogastric tube) for 21 days. Finally, urea, uric acid, creatinine parameters, and the diameter of some key or important parts of the kidney were measured in different animal groups.

Results: it was found that the use of AZA (50 mg/kg) increased serum urea and creatinine concentrations, blood uric acid in comparison to the group of control ( $P<0.05)$. Whereas injecting ZOE (200 $\mathrm{mg} / \mathrm{kg})$ induces a considerable decrease in the concentration of the compounds mentioned above as compared to control animals and animals given AZA $(P<0.05)$. Furthermore, the findings revealed that AZA caused inflammation and kidney tissue destruction, while ZOE improved, restored, and recovered the affected kidney tissue.

Conclusion: according to the research findings, it can be decided that ZOE has a protective and therapeutic impact on kidney tissue owing to its strong antioxidant attributes and its ability to inhibit free radicals produced by azathioprine

Keywords: renal damage, Zingiber officinale, Azathioprine, animal model

How to cite:

Shareef, S. M., Khaleel, R. A., Hameed, Z. E., Alsaraf, K. M. (2021). The protective effect of Zingiber officinale L. extract on kidney tissues and blood factors of kidney functions after the damage caused by Azathioprine. ScienceRise: Pharmaceutical Science, 4 (32), 78-86. doi: http://doi.org/10.15587/2519-4852.2021.239434

(C) The Author(s) 2021

This is an open access article under the Creative Commons CC BY license hydrate

\section{Introduction}

Azathioprine (AZA), marketed under the brand/trade name Imuran, is a derivative of mercaptopurine (6-MP) with the molecular formula $\mathrm{C}_{9} \mathrm{H}_{7} \mathrm{~N}_{7} \mathrm{O}_{2} \mathrm{~S}$. It is a drug used to cure several disorders, including rheumatoid arthritis, vasculitis myositis, kidney transplants (to prevent its rejection), and some other rheumatic diseases are prescribed [1]. In addition, AZA is an immunosuppressive medication that decreases the immune reactions in the body [2]. Moreover, AZA can also be used to treat some cancers and inflammatory intestine diseases, decreasing pain and inflammation, reducing joint damage, and preventing longstanding incapacity [3].

AZA inhibits the immune system by preventing the reproduction of purine bases and inhibiting DNA and RNA synthesis by disrupting lymphocyte activity and thus preventing lymphocytes from entering or invading connective tissues and joints in rheumatic diseases [4]. AZA poisons various organs, including the bone marrow, kidneys, gastrointestinal tract, and pancreas, by producing free radicals [5]. The thiopurine methyltransferase (TPMT) and xanthine oxidase (XO) enzymes rapidly metabolize AZA to inactive substances in the body, so their inactivity enhances the formation of toxic metabolites [6, 7]. Azathioprine cause abnormal and structural changes in the cell, chromosome fragmentation, reduced mitotic division, and increased the number of cells with multiple chromosomes, according to the findings of a study [8].

Ginger is a medicinal plant from the Zingiberaceae family known as Zingiber officinale $L$., founded in East Asia, especially India [9]. Ordinary or usual Ginger is the well-known species in this genus, reaching $100-120 \mathrm{~cm}$ and remaining stable due to its plant rhizome [10]. The chemical compounds Zingerone, Gingerols, Shogalos, and volatile oils, which make up three percent by weight of Ginger, are responsible for its distinct special smell, taste, and flavour. Ginger consumption improves antioxidant enzyme activity and helps to reduce free radicals. Antiinflammatory effects have already been documented in ginger extract (GIE) [11, 12]. GIE could transform immune responses that intensify inflammation at the cellular level. Ginger improves antioxidant systems and absorbs plasma free radicals, making it strong antioxidants [13]. Antioxidant and anti-inflammatory ingredients in GIE, including 6 Gingerols, 6 Shogalos, and Zingerone, can impact anti-inflammatory and anti-serotonin processes to reduce inflammatory factors such as inflammatory chemokine, reducing antioxidant enzymes, and reduce the reduction of complications [14]. 
Previous research showed that in rats with kidney damage, ethyl acetate extract of Ginger, probably with antioxidant properties, has significant protective properties in kidney tissues versus high dose paracetamol [9]. Polyphenols and flavonoids in the GIE inhibit antioxidant, antioxidant enzymes, and polyphenols and flavonoids mediate these protective effects [15]. Ginger's oral intake has been shown in research to have no adverse impact on the liver, kidneys, and pancreas [16]. When combined with the antiepileptic drug lamotrigine, Ginger decreases the drug's side effects in the kidney, reducing serum urea and creatinine levels and improving glomeruli and convoluted tubules in rats treated with this drug [17]. Due to alcohol intake, consuming a hydroalcoholic extract (HAE) of Ginger improves or recovers renal impairment and significantly reduces plasma concentrations of creatinine, urea, and cystatin C [18]. Laboratory studies show that Ginger has anti-inflammatory effects by inhibiting cyclooxygenase and lipoxygenase pathways and inhibiting arachidonic acid metabolism [19]. In addition, GIE prevents the production of prostaglandins, including prostaglandin E2, by inhibiting the enzyme cyclooxygenase 2 , which is involved in the production synthesis of prostaglandins in inflamed tissues, thereby inhibiting the production of reactive oxygen species and tissue oxidation [20]. Because of the nephrotoxic effects of azathioprine, it is necessary to look for natural or herbal medicines with few side effects to counteract the damage caused by azathioprine. Oral ingestion of ginger powder has been shown in one study to have no negative effects on the liver, kidneys, or pancreas [16]. The main reason of this experimental study was to estimate the beneficial influence of ZOE on azathioprineinduced renal impairment (AZA) in an animal (mature female rats) model.

\section{Planning (methodology) of research}

The methodology was designed as following Fig. 1 to attain the aim of the research.

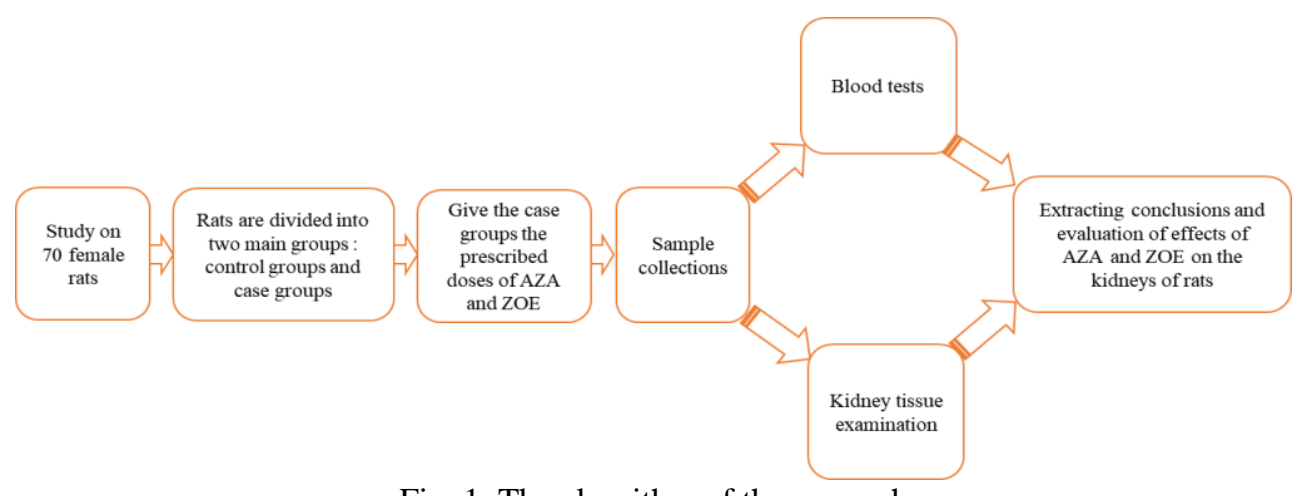

Fig. 1. The algorithm of the research

\section{Material and Methods}

\subsection{Ethical consideration}

The present study was submitted to and approved by the animal ethics framework under the supervision of the Institute for the Prevention of Cruelty to Animals and Research Council. Moreover, it was ethically approved by the ethical council of the research of the Al-esraa university college, Iraq (456/lq) on 12.10.2020. The European Council Directive (2010/63/EU) recommendations of September 22, 2010, regarding the standards in protecting animals used for experimental purposes, was also followed.

\subsection{Selection and maintenance of animals}

This study was conducted in the laboratories of the Department of pharmacy, Al-esraa University College. Firstly, 70 adult female Wistar rats weighing $200 \pm 10 \mathrm{~g}$ and aged $95 \pm 5$ days were chosen for this research, an experimental study. During the administration time, all animals take the same water and food without restriction. Rats were held in a special room with 12 hours of light and 12 hours of darkness at a temperature of $25 \pm 2{ }^{\circ} \mathrm{C}$. The ethical principles of laboratory animals were observed during the experiment, and all tests were performed throughout the light period [9].

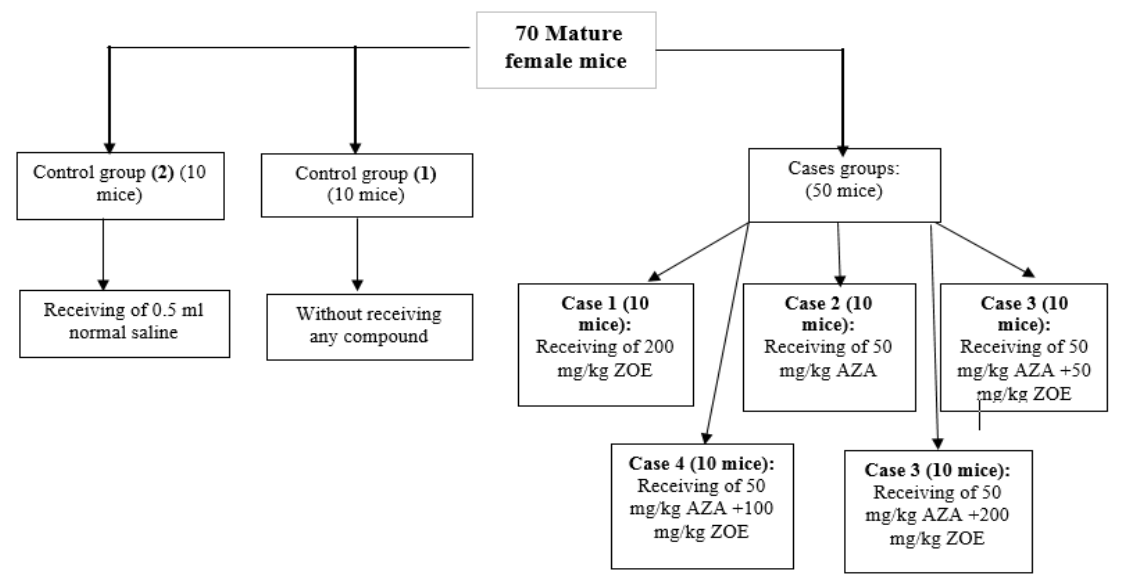

Fig. 2. Animal grouping procedure in the present study [AZA: Azathioprine; ZOE: Zingiber officinale L. extract]. 


\subsection{Animal grouping}

After completing all rat cycles [20, 21], the animals were divided into seven groups of ten, with two control groups and five groups receiving HAE of Ginger, azathioprine, and normal saline (Fig. 2). Table 1 shows groups included in the present study. AZA was given intraperitoneally in this study, and ZOE was given by gavage for 21 days [9].

The following abbreviations were used to summarize the names of the groups studied in this study.

Table 1

Animal groups were included in the present study.

\begin{tabular}{|c|c|}
\hline Groups & Defenition \\
\hline Group 1(G1) & Without any injection \\
\hline Group 2 (G2) & $\begin{array}{l}\text { Receiving of } 0.5 \mathrm{ml} \text { normal saline, intraperitoneally and by gavage (nasogastric } \\
\text { tube) daily as a drug solvent }\end{array}$ \\
\hline Group 3 (G3) & Receiving only $200 \mathrm{mg} / \mathrm{kg} \mathrm{ZOE}$ \\
\hline Group 4 (G4) & Receiving only $50 \mathrm{mg} / \mathrm{kg}$ AZA \\
\hline Group 5 (G5) & Receiving of $50 \mathrm{mg} / \mathrm{kg} \mathrm{AZA}+50 \mathrm{mg} / \mathrm{kg} \mathrm{ZOE}$ \\
\hline Group 6 (G6) & Receiving of $50 \mathrm{mg} / \mathrm{kg} \mathrm{AZA}+100 \mathrm{mg} / \mathrm{kg} \mathrm{ZOE}$ \\
\hline Group 7 (G7) & Receiving of $50 \mathrm{mg} / \mathrm{kg} \mathrm{AZA}+200 \mathrm{mg} / \mathrm{kg} \mathrm{ZOE}$ \\
\hline
\end{tabular}

\subsection{Preparation of $\mathrm{ZOE}$}

Ginger root extract was prepared using the percolation method in the present study. To provide and make it, prepare a sufficient amount of ginger root, clean and dry it, grind it to a powder, and then pour a sufficient amount of the powder into the percolator for 72 hours with $1000 \mathrm{ml}$ of $50 \%$ ethanol to soak properly, and completely. Then the liquid drips into the lower container when the percolator valve is opened. Next, a pipette was used to continuously add solvent (alcohol) to the top of the bottle to prevent the plant powder from drying out. After that, a rotary apparatus (rotavapor) was applied to separate the liquid collected under the percolator from the excess solvent until it was completely condensed, including an alcoholic solvent and a complete extraction. Then use a vacuum pump and a desiccator, the extract became powdered [9].

\subsection{Blood sampling and measurement of stud-} ied parameters

Following rats' ether anesthesia, blood samples were selected from their hearts using an insulin syringe to measure serum levels of creatinine, bilirubin, and urea. Blood samples were incubated at $37^{\circ} \mathrm{C}$ for 15 minutes before being centrifuged at $5000 \mathrm{rpm}$ for $15 \mathrm{~min}$. Creatinine was measured using the Jaffe / Fixed Rate or Kinetic method, while urea and uric acid were measured using the Berthelot / Endpoint method in this research. Following blood collection of the animals, each animal's left and right kidneys were separated and measured with a digital scale with a precision of $0.001 \mathrm{~g}$ after removing all other additional tissues, then put in containers containing $10 \%$ formalin stabilizer. To prepare tissue cross-sections, and then to analyse the histological investigation of the kidneys and to prepare tissue sections after dehydration and remoulding, tissue sections with a layer of 5 microns were prepared using a rotary microtome system (LEIYZ, Australia, Model: 1512) and after staining with hematoxylin and eosin stain using a Nikon microscope made in Japan, the degree of inflammation and necrosis of kidney tissue was measured semi-quantitatively and as a result; absence of histological changes (zero degrees), minor histological changes (first degree), moderate histological changes (second degree), severe histological changes (third-degree) were measured.

\subsection{Pathomorphological evaluation}

To study the structure of the kidneys and to prepare tissue sections after drying out and moulding, tissue sections with a thickness of 5 microns were prepared using a rotary microtome system (LEIYZ, Australia, Model: 1512) and after staining with hematoxylin and eosin stain using a Nikon microscope made in Japan, examined the degree of inflammation and necrosis of kidney tissue in a semi-quantitative manner. Histological changes were graded based on their absence (zero degrees), minor histological changes (first degree), moderate histological changes (second degree), and severe histological changes (third-degree).

\subsection{Statistical analysis}

The obtained findings of serological and histological variables were compared between various case and control groups using a one-way ANOVA test at a significant level $(\alpha=0.05)$.

\section{Results}

According to the findings, the use of AZA (50 $\mathrm{mg} / \mathrm{kg}$ ) in $\mathrm{G} 4$ increased the serum levels of blood urea, creatinine, and uric acid compared to the control group $(\mathrm{P}<0.05)$. While injection of ZOE $(200 \mathrm{mg} / \mathrm{kg})$ in $\mathrm{G} 3$ caused a considerable reduction in serum level of urea, creatinine, and uric acid compared to animals in the control and G4 groups $(\mathrm{P}<0.05)$. Serum levels of urea, uric acid, and creatinine were not considerably different between G4 and G5 $(\mathrm{P}>0.05)$, but the concentrations of the compounds mentioned above in G6 and G7 were significantly decreased compared to G4 $(\mathrm{P}<0.05)$ (Table 2 and Fig. 2).

The results showed that injection of AZA and ZOE in G3 and G4, respectively, did not cause a significant effect on the size of the renal cortex diameter $(\mathrm{P}>0.05)$, while the renal cortex diameter in G6 and G7 was considerably decreased compared to $\mathrm{G} 3(\mathrm{P}<0.05)$. According to the present study's findings, compared to the control group, the diameter of the medulla of the kidney in G3 and G4, respectively, increased and decreased significantly $(\mathrm{P}<0.05)$. Renal medulla diameter decreased significantly in G6 and G7 compared to G3 $(\mathrm{P}<0.05)$. The diameter of Renal Corpuscle and Glomerulus in G3 was not significantly different from the control group $(\mathrm{P}>0.05)$, while in $\mathrm{G} 4$, it was considerably decreased compared to the control group $(\mathrm{P}<0.05)$. The 
results also showed that the diameters of Renal Corpuscle and Glomerulus in G5 and G7 were not considerably different from $\mathrm{G} 3(\mathrm{P}>0.05)$, while the diameter of Glomerulus in G6 was considerably decreased compared to G3 $(\mathrm{P}<0.05)$ (Table 3, Fig. 4, 5).

The diameters of the renal capsule, proximal and distal tubule, and collecting tube sections were not considerably different in all of the studied groups (including G4, G5, G6, and G7) compared to G3 or the control group $(\mathrm{P}>0.05)$. The Loop diameter of Henle between G3 and the control group was not significantly different $(\mathrm{P}>0.05)$, while the diameter of this part of the kidney in G4 was significantly smaller $(\mathrm{P}<0.05)$ than in G3. In addition, the diameter of the Loop of Henle in G5, G6, and G7 was not significantly different from G3 (P>0.05), according to the measurements (Table 3, Fig. 4, 5).

Tissue images prepared from the renal tissue section in different groups show the kidneys' completely healthy and normal tissue structure without any effect of hyperemia, dilation of veins, tubular necrosis, inflammatory cell infiltration, and glomerular changes tissue sections in control, control groups, and in $\mathrm{ZOE}=200 \mathrm{mg} / \mathrm{kg}$ recipient group.

While animals received AZA alone and along with $\mathrm{ZOE}=50 \mathrm{mg} / \mathrm{kg}$ compared with the control group, lesions such as cell necrosis, tubular destruction, shrinking glomeruli, enlarged urinary space, hyperemia and inflammatory cell infiltration It is observed in kidney tissue. Also, tissue images represent less cell necrosis (dark nuclei), less tubular destruction, less infiltration of inflammatory cells, normalization of glomerular structure, and reduced destructive effects of AZA in animals receiving AZA along with $\mathrm{ZOE}=100 \mathrm{mg} / \mathrm{kg}$. In addition, very mild cell necrosis (dark nuclei), very mild tubular degradation, very low infiltration of inflammatory cells, normalization of glomerular structure indicating a reduction in the destructive effects of AZA by $\mathrm{ZOE}=200 \mathrm{mg} / \mathrm{kg}$ (Fig. 6).

Table 2

The descriptive and analytical parameters of serological factors for different studied groups

\begin{tabular}{|c|c|c|c|c|c|c|c|c|}
\hline \multirow{3}{*}{$\begin{array}{l}\text { Serological } \\
\text { factors }\end{array}$} & \multicolumn{8}{|c|}{$\begin{array}{ll} & \text { Studied groups } \\
\end{array}$} \\
\hline & \multirow[t]{2}{*}{$\begin{array}{c}\text { Descriptive and } \\
\text { analytical pa- } \\
\text { rameters }\end{array}$} & $\begin{array}{l}\text { Control } \\
\text { (1) }\end{array}$ & $\begin{array}{c}\text { Control } \\
(2)\end{array}$ & $\begin{array}{c}\text { AZA } \\
50 \mathrm{mg} / \mathrm{kg}\end{array}$ & $\begin{array}{c}\mathrm{ZOE} \\
(200 \mathrm{mg} / \mathrm{kg})\end{array}$ & $\begin{array}{c}\mathrm{ZOE} \\
50 \mathrm{mg} / \mathrm{kg}+ \\
+\mathrm{AZA} 50 \mathrm{mg} / \mathrm{kg}\end{array}$ & $\begin{array}{c}\mathrm{ZOE} \\
100 \mathrm{mg} / \mathrm{kg}+ \\
+\mathrm{AZA} \\
50 \mathrm{mg} / \mathrm{kg}\end{array}$ & $\begin{array}{c}\text { ZOE } \\
200 \mathrm{mg} / \mathrm{kg}+ \\
+\mathrm{AZA} \\
50 \mathrm{mg} / \mathrm{kg}\end{array}$ \\
\hline & & G1 & G2 & G3 & G4 & G5 & G6 & G7 \\
\hline \multirow{4}{*}{$\begin{array}{l}\text { Urea } \\
(\mathrm{mg} / \mathrm{dl})\end{array}$} & Mean & 20.75 & 20.67 & $30.91 *$ & $20.68 * *$ & 29.61 & 22.08 & 23.42 \\
\hline & SD & 1.49 & 1.43 & 1.41 & 1.65 & 1.57 & 0.74 & 0.545 \\
\hline & Min & 18.31 & 17.99 & 28.12 & 17.94 & 27.44 & 20.98 & 22.35 \\
\hline & Max & 23.13 & 22.93 & 32.70 & 22.97 & 31.82 & 23.87 & 24.00 \\
\hline \multirow{4}{*}{$\begin{array}{l}\text { Uric acid } \\
(\mathrm{mg} / \mathrm{dl})\end{array}$} & Mean & 1.70 & 1.69 & $3.79 *$ & $1.34 * *$ & 3.50 & 1.98 & 2.01 \\
\hline & SD & 0.06 & 0.08 & 0.21 & 0.14 & 0.28 & 0.15 & 0.20 \\
\hline & Min & 1.62 & 1.58 & 3.52 & 1.19 & 3.07 & 1.76 & 1.71 \\
\hline & Max & 1.78 & 1.84 & 4.06 & 1.57 & 4.05 & 2.21 & 2.30 \\
\hline \multirow{4}{*}{$\begin{array}{l}\text { Creatinine } \\
(\mathrm{mg} / \mathrm{dl})\end{array}$} & Mean & 0.61 & 0.61 & $0.83^{*}$ & $0.59 * *$ & 0.75 & 0.65 & 0.64 \\
\hline & SD & 0.02 & 0.04 & 0.02 & 0.01 & 0.02 & 0.02 & 0.02 \\
\hline & Min & 0.59 & 0.56 & 0.78 & 0.58 & 0.71 & 0.61 & 0.60 \\
\hline & Max & 0.65 & 0.70 & 0.86 & 0.60 & 0.80 & 0.70 & 0.68 \\
\hline
\end{tabular}

Note: $*-P<0.05$ compared to the control group, $* *-P<0.05$ compared to the control group to animals in the control and $G 4$ groups, AZA - Azathioprine, ZOE - Zingiber officinale L. extract, SD - Standard deviation, Min-Minimum, Max-Maximum
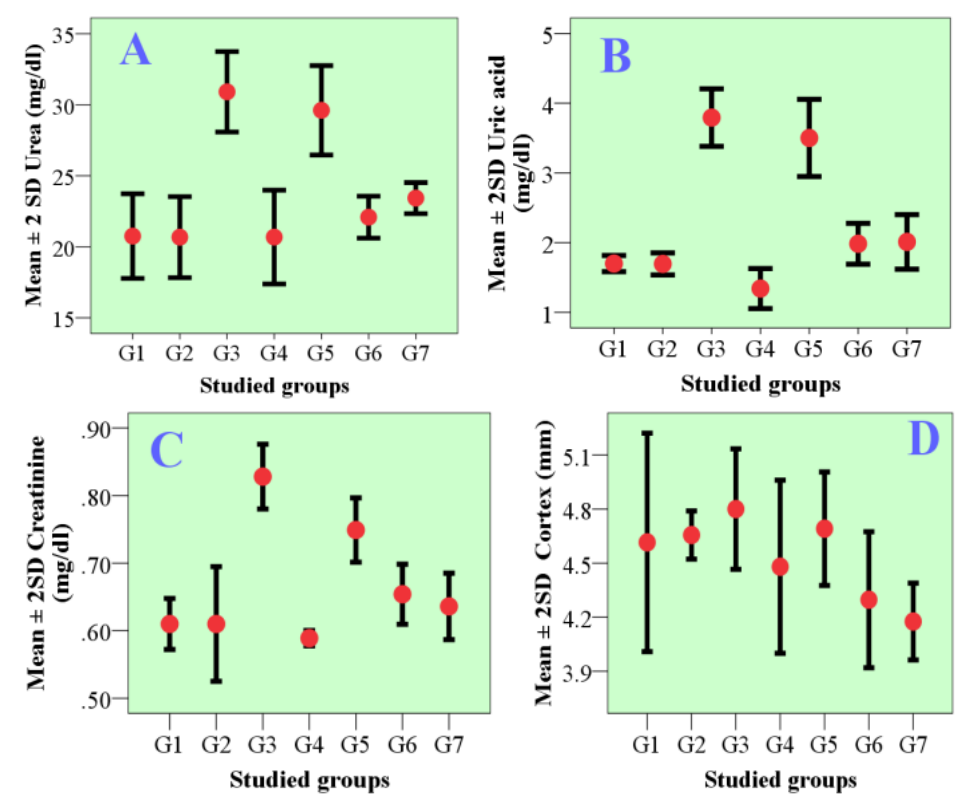

Fig. 3. The comparison of Urea (A), Uric acid (B), Creatinine (C), and Cortex (D) between different studied groups 
Table 3

The descriptive and analytical parameters of histological factors for different studied groups

\begin{tabular}{|c|c|c|c|c|c|c|c|c|}
\hline \multirow{3}{*}{$\begin{array}{l}\text { Histological } \\
\text { factors }\end{array}$} & \multicolumn{8}{|c|}{ Studied groups } \\
\hline & \multirow[t]{2}{*}{$\begin{array}{l}\text { Descriptive } \\
\text { and analyti- } \\
\text { cal parame- } \\
\text { ters }\end{array}$} & $\begin{array}{l}\text { Control } \\
\text { (1) }\end{array}$ & $\begin{array}{l}\text { Control } \\
\text { (2) }\end{array}$ & $\begin{array}{c}\text { AZA } \\
50 \mathrm{mg} / \mathrm{kg}\end{array}$ & $\begin{array}{c}\mathrm{ZOE} \\
200 \mathrm{mg} / \mathrm{kg}\end{array}$ & $\begin{array}{c}\mathrm{ZOE} \\
50 \mathrm{mg} / \mathrm{kg}+ \\
+\mathrm{AZA} \\
50 \mathrm{mg} / \mathrm{kg} \\
\end{array}$ & $\begin{array}{c}\mathrm{ZOE} \\
100 \mathrm{mg} / \mathrm{kg}+ \\
+\mathrm{AZA} \\
50 \mathrm{mg} / \mathrm{kg} \\
\end{array}$ & $\begin{array}{c}\mathrm{ZOE} \\
200 \mathrm{mg} / \mathrm{kg}+ \\
+\mathrm{AZA} \\
50 \mathrm{mg} / \mathrm{kg} \\
\end{array}$ \\
\hline & & G1 & G2 & G3 & G4 & G5 & G6 & $\mathrm{G} 7$ \\
\hline \multirow{4}{*}{$\begin{array}{l}\text { Cortex } \\
(\mathrm{mm})\end{array}$} & Mean & 4.61 & 4.66 & 4.80 & 4.48 & 4.69 & $4.30 *$ & $4.18 *$ \\
\hline & $\mathrm{SD}$ & 0.30 & 0.07 & 0.17 & 0.24 & 0.16 & 0.19 & 0.11 \\
\hline & Min & 4.05 & 4.51 & 4.54 & 4.07 & 4.47 & 3.99 & 4.00 \\
\hline & Max & 5.08 & 4.76 & 5.03 & 4.80 & 4.91 & 4.64 & 4.36 \\
\hline \multirow{4}{*}{$\begin{array}{l}\text { Medulla } \\
\quad(\mathrm{mm})\end{array}$} & Mean & 6.38 & 6.43 & $6.69 * *$ & $6.00 * *$ & 6.72 & $6.00 *$ & $5.85^{*}$ \\
\hline & $\mathrm{SD}$ & 0.19 & 0.16 & 0.13 & 0.14 & 0.04 & 0.25 & 0.20 \\
\hline & Min & 6.11 & 6.15 & 6.49 & 5.68 & 6.64 & 5.61 & 5.59 \\
\hline & Max & 6.69 & 6.73 & 6.89 & 6.20 & 6.76 & 6.42 & 6.21 \\
\hline \multirow{4}{*}{$\begin{array}{l}\text { Renal Cor- } \\
\text { puscle } \\
(\mathrm{mm})\end{array}$} & Mean & 0.349 & 0.355 & 0.396 & 0.281 & 0.366 & 0.345 & 0.347 \\
\hline & $\mathrm{SD}$ & 0.019 & 0.017 & 0.014 & 0.027 & 0.042 & 0.008 & 0.023 \\
\hline & Min & 0.324 & 0.331 & 0.380 & 0.251 & 0.308 & 0.336 & 0.310 \\
\hline & Max & 0.386 & 0.390 & 0.418 & 0.336 & 0.441 & 0.361 & 0.383 \\
\hline \multirow{4}{*}{$\begin{array}{l}\text { Glomerulus } \\
(\mathrm{mm})\end{array}$} & Mean & 0.272 & 0.278 & 0.305 & 0.208 & 0.292 & $0.21 * 8$ & 0.252 \\
\hline & SD & 0.025 & 0.014 & 0.024 & 0.020 & 0.020 & 0.006 & 0.022 \\
\hline & Min & 0.224 & 0.257 & 0.269 & 0.179 & 0.259 & 0.202 & 0.221 \\
\hline & Max & 0.305 & 0.299 & 0.349 & 0.241 & 0.324 & 0.225 & 0.288 \\
\hline \multirow{4}{*}{$\begin{array}{l}\text { Renal Cap- } \\
\text { sule (mm) }\end{array}$} & Mean & 0.029 & 0.039 & 0.039 & $0.030 * * \#$ & 0.040 & 0.030 & 0.040 \\
\hline & $\mathrm{SD}$ & 0.001 & 0.006 & 0.002 & 0.003 & 0.009 & 0.006 & 0.003 \\
\hline & Min & 0.028 & 0.031 & 0.035 & 0.028 & 0.030 & 0.023 & 0.035 \\
\hline & $\operatorname{Max}$ & 0.032 & 0.053 & 0.042 & 0.036 & 0.054 & 0.043 & 0.046 \\
\hline \multirow{4}{*}{$\begin{array}{l}\text { Proximal } \\
\text { tubule } \\
(\mathrm{mm})\end{array}$} & Mean & 0.120 & 0.117 & 0.109 & 0.109 & 0.121 & 0.119 & 0.109 \\
\hline & SD & 0.008 & 0.007 & 0.004 & 0.006 & 0.007 & 0.006 & 0.005 \\
\hline & Min & 0.109 & 0.106 & 0.103 & 0.102 & 0.114 & 0.110 & 0.102 \\
\hline & Max & 0.136 & 0.128 & 0.114 & 0.122 & 0.132 & 0.133 & 0.119 \\
\hline \multirow{4}{*}{$\begin{array}{l}\text { Distal tu- } \\
\text { bule } \\
\text { (mm) }\end{array}$} & Mean & 0.071 & 0.069 & 0.080 & 0.071 & 0.080 & 0.070 & 0.078 \\
\hline & $\mathrm{SD}$ & 0.004 & 0.003 & 0.004 & 0.002 & 0.001 & 0.003 & 0.008 \\
\hline & Min & 0.064 & 0.064 & 0.074 & 0.068 & 0.078 & 0.063 & 0.063 \\
\hline & Max & 0.076 & 0.076 & 0.084 & 0.073 & 0.082 & 0.077 & 0.088 \\
\hline \multirow{4}{*}{$\begin{array}{l}\text { Collecting } \\
\text { tube } \\
(\mathrm{mm})\end{array}$} & Mean & 0.088 & 0.101 & 0.101 & 0.102 & 0.087 & 0.100 & 0.092 \\
\hline & $\mathrm{SD}$ & 0.002 & 0.010 & 0.004 & 0.005 & 0.006 & 0.003 & 0.006 \\
\hline & Min & 0.084 & 0.087 & 0.093 & 0.095 & 0.080 & 0.095 & 0.083 \\
\hline & Max & 0.091 & 0.122 & 0.106 & 0.109 & 0.094 & 0.104 & 0.102 \\
\hline \multirow{4}{*}{$\begin{array}{l}\text { Loop of } \\
\text { Henle } \\
(\mathrm{mm})\end{array}$} & Mean & 0.048 & 0.059 & 0.060 & $0.040 *$ & 0.048 & 0.048 & 0.048 \\
\hline & $\mathrm{SD}$ & 0.005 & 0.002 & 0.003 & 0.003 & 0.004 & 0.003 & 0.004 \\
\hline & Min & 0.042 & 0.056 & 0.055 & 0.036 & 0.041 & 0.042 & 0.041 \\
\hline & Max & 0.055 & 0.062 & 0.064 & 0.047 & 0.054 & 0.052 & 0.054 \\
\hline
\end{tabular}

Note: $*-P<0.05$ compared to G3, ** $-P<0.05$ compared to the control group, AZA - Azathioprine, ZOE - Zingiber officinale L. extract, SD - Standard deviation, Min - Minimum, Max-Maximum 

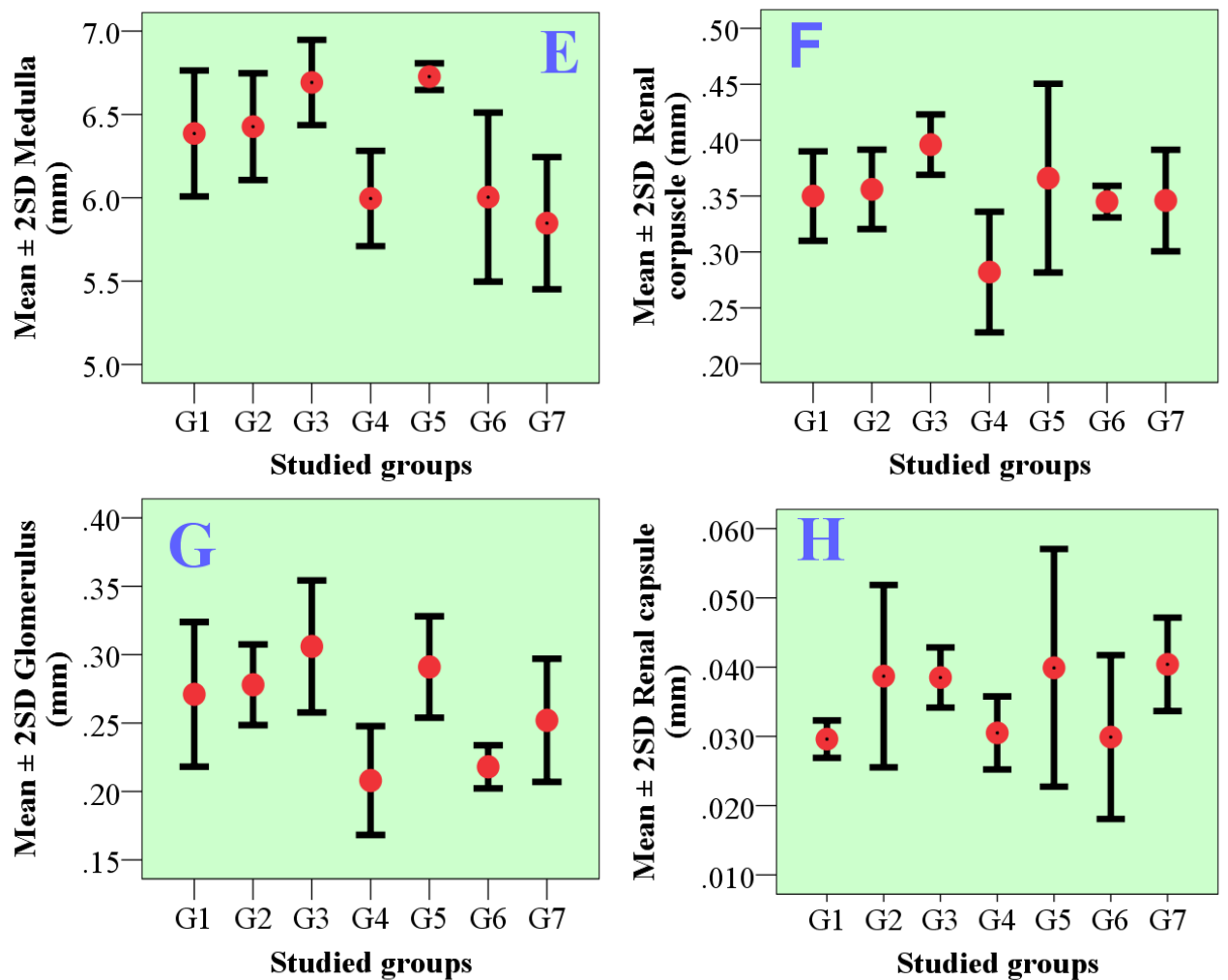

Fig. 4. The comparison of Medulla (E), Renal corpuscle (F), Glomerulus (G), and Renal capsule (H) of different studied groups
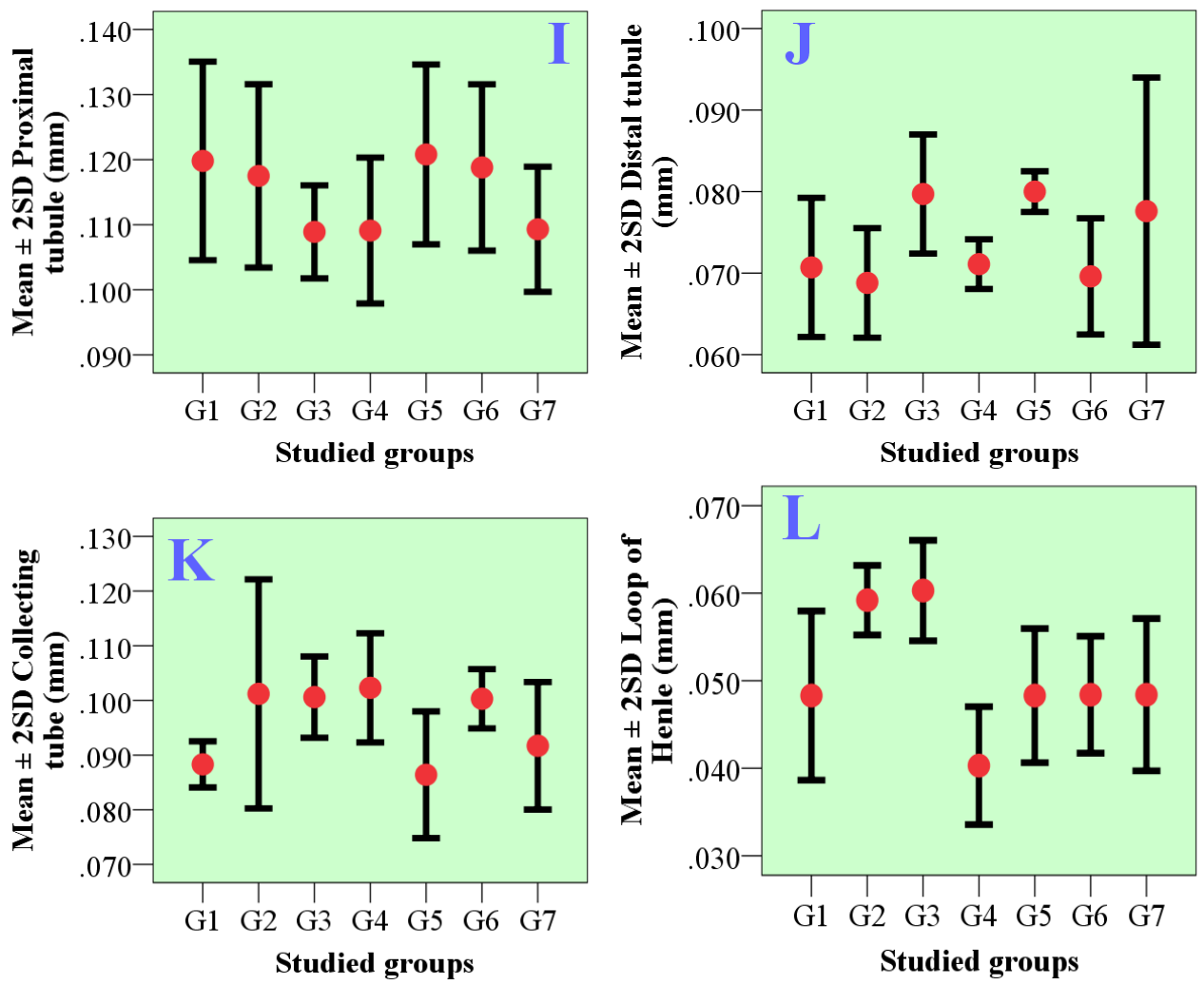

Fig. 5. The proximal tubule (I), Distal tubule (J), Collecting tube (K), and Loop of Henle (L) between different studied groups 
A

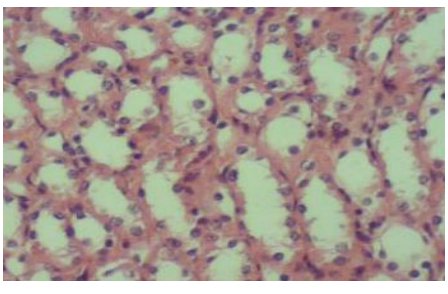

C

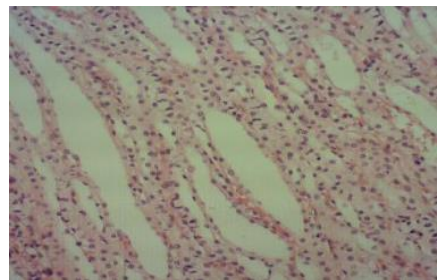

$\mathbf{E}$

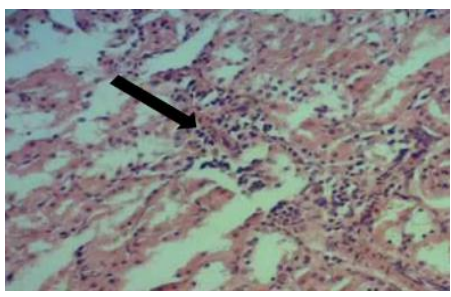

G

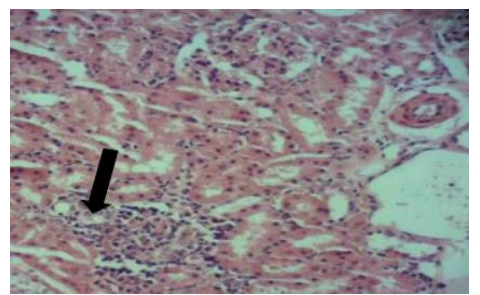

B

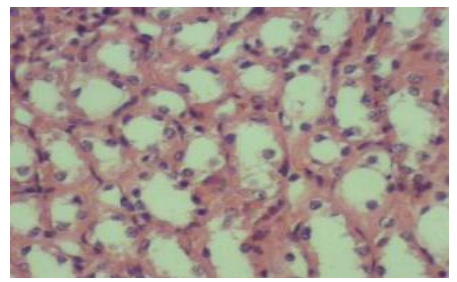

D

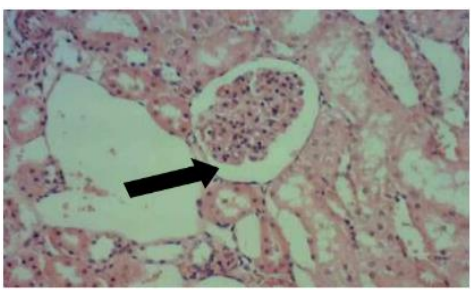

F

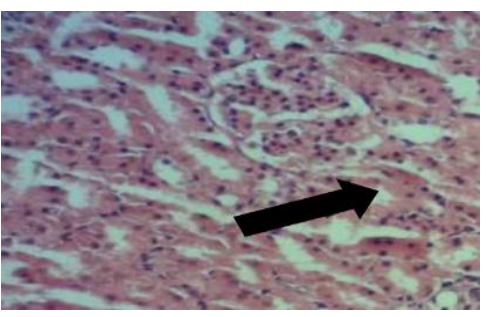

H

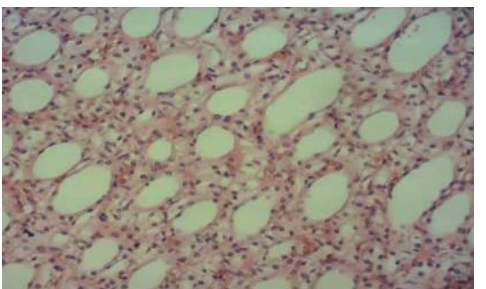

Fig. 5. Hematoxylin and eosin-stained sections of photomicrographs of kidney tissue with a magnification of 100 in different groups of animals received ZOE and AZA

Kidney tissue photomicrographs in animals of the control group (1) which shows the completely healthy structure of kidney tissue (A), Kidney tissue photomicrographs in animals of the control group (2) which shows a completely healthy structure of kidney tissue (B), Kidney tissue photomicrographs in animals received the $200 \mathrm{mg} / \mathrm{kg}$ ZOE group, which represents the completely healthy structure of kidney tissue (C), photomicrographs of kidney tissue in animals received the $50 \mathrm{mg} / \mathrm{kg}$ AZA group, indicating damage to kidney tissue (including, cell necrosis, tubular destruction, glomerular shrinkage, and enlargement of the urethra (D), photomicrographs of kidney tissue in animals received $50 \mathrm{mg} / \mathrm{kg} \mathrm{AZA}+50 \mathrm{mg} / \mathrm{kg} \mathrm{ZOE}$, indicating less damage than $\mathrm{D}$ picture (due to take of ZOE) (E), Kidney tissue photomicrographs in animals received $50 \mathrm{mg} / \mathrm{kg} \mathrm{AZA}+100$ $\mathrm{mg} / \mathrm{kg}$ ZOE, indicating less cell necrosis, less tubular destruction, inflammatory cell infiltration, and normalization of a glomerular structure ( $\mathrm{F}$ and $\mathrm{G})$, Kidney tissue photomicrographs in animals received $50 \mathrm{mg} / \mathrm{kg} \mathrm{AZA}+200 \mathrm{mg} / \mathrm{kg}$ ZOE, indicating no cell necrosis, very mild tubular destruction, very low infiltration of inflammatory cells, and normalization of a glomerular and tubular structure $(\mathrm{H})$.

\section{Discussion}

Injection of the AZA drug induces cell necrosis, tubular destruction, shrinking glomeruli, enlarged urinary bladder, hyperemia, infiltration of inflammatory cells in kidney tissue, and increases serum urea, creatinine, and uric acid, as per the results. Various medications perhaps directly affect the kidney, that is, the body's main filtration and detoxification site [1-5]. Moreover, metabolites from several internal and external toxins damage the kidneys' tissue structure and function [6-9]. When the renal parenchyma was impaired, serum amounts of urea, creatinine and uric acid increased, according to a study by Gad and Zaghloul (2013). According to the same study results, damage and destruction of the false legs of glomerular podocytes decrease their interaction with the glomerular basement membrane and hence reduce glomerular filtration-finally, urea and creatinine in the blood increase due to the above complications [22]. As a part of the present study's findings and the negative effects of AZA, it can be concluded that AZA-induced kidney damage increases the amounts of urea, uric acid, and blood creatinine. Since these three factors, including uric acid, urea, and creatinine, are warded off by the kidneys, as the kidneys are damaged or impaired and inflamed by a toxic agent (e.g., AZA), the concentration of the above three factors enters the bloodstream and their concentration in the blood increases [8, 9]. The current study's findings were similar to those of past research of a similar study. For example, the findings of a study by Ele- 
laimy et al. (2012) showed that the use of AZA significantly increased serum creatinine and significantly decreased glomerular filtration rate, and also decreased creatinine clearance compared to the group receiving Mycophenolate Mofetil drugs. AZA was shown to disrupt and defect the antioxidant system in the tissues of all rats in the present research [23]. Additionally, Akinlolu et al. (2017) reported that the mechanism of AZA damage to the kidneys is as follows: the drug increases oxidative stress and lipid peroxidation, increases malondialdehyde and causes nephrotoxic effects and dysfunction, and also impaired enzymatic activity of antioxidant enzymes in kidney tissue, which ultimately affects the structure and function of the kidneys and thus increases serum levels of urea, creatinine and uric acid in the blood [24].

$\mathrm{ZOE}$ has a protective effect on the kidney cells of lead-poisoned immature rats, according to Johari et al. (2013), and this defensive outcome is primarily due to its phenolic and ethanolic substances, which neutralize free radicals and improve kidney cell repair due to their antioxidant characteristics [25]. Hosseini and Mirazi (2014) reported that ZOE had the strongest effect on the threshold of tonic-clonic seizures in epileptic rats than the control group in the research on male rats receiving pentylenetetrazole-induced seizures treated with HAE of the ginger extract [26]. Moalem et al. (2003) showed that this plant's aqueous and alcoholic extracts cause teratogenic effects in Syrian rat embryos [27]. According to Zekrizadeh and Farokhy's (2014) studies, and HAE of Ginger can help repair damaged kidney tissue in epileptic seizure rats treated with lamotrigine [17].

Quercetin is one of the flavonoids in ZOE, which has antioxidant properties [28]. Various studies have reported that quercetin has protective effects versus toxic or harmful factors to the liver, heart, kidneys, neurons, and DNA [29-31]. Moreover, ZOE has other antioxidant and protective properties against harmful and free radicals referred to as vitamin B and C [32]. As a result, the strong antioxidant properties of the compounds in this plant and the oxidative effects of $\mathrm{ZOE}$ can reduce the destructive effects of AZA on renal function. Anomalies in kidney tissue structure in animals given AZA are caused by DNA or chromosomal damage, which causes cell necrosis and glomerular membrane damage [23]. The cortex tissue of the kidney becomes rough and irregular after kidney damage, and scar tissue forms in the glomeruli and urinary bladder. In addition, the renal artery thickens, and ion filtration routes are disrupted when the kidneys are damaged, resulting in severe glo- merular damage. Since most drugs induce an oxidative reaction and alter the permeability of cell membranes, it will upset the ionic balance, so AZA will likely damage the tissue structure of the kidney by the same mechanism [5]. As a result of the findings of this study, ZOE with antioxidant properties and the protective effects versus different nephrotoxins will improve kidney tissue impairment affected by AZA [28].

Study limitations. Due to financial constraints, it was not possible to test more laboratory animals. In addition, only two analyzes of the desired compounds were performed in the blood of different groups.

Prospects for further research. To achieve better results for use to protect human health, the results of this animal study and other similar studies must be translated into human-applicable results. To do this, uncertainty factors (safety factors) must be used. These factors are used because of the differences in the metabolism of the human and animal bodies and the extrapolation of animal-to-human data.

\section{Conclusion}

According to the present research finding, it may be inferred that azathioprine damages the kidneys' tissue structure, and the amount of blood urea, creatinine, and uric acid are increased. Moreover, the findings of this experimental research presented that the hydroalcoholic extract of Ginger probably has a defensive result on kidney tissue due to its strong antioxidant properties and inhibition of free radicals produced by azathioprine, so this plant compound reduces the severity of azathioprine's destructive effects on the tissue structure of the kidney through the above-mentioned protective mechanism. Eventually, it can be established that the hydroalcoholic extract of Ginger reduces the amount of urea, creatinine, and uric acid in the blood by improving the tissue of the kidneys damaged by azathioprine.

\section{Competing interests}

The authors declare that they have no competing interests.

\section{Funding/support}

The study was performed without financial support.

\section{Acknowledgments}

We would like to Acknowledgment the Department of pharmacy, Al-esraa university college, for providing the facilities to conduct the experimental part.

\section{References}

1. Daim, N. E., Al-Mayali, H. K. (2020). Effect of the rutin on azathioprine-induced toxicity in reproductive function male rats. Eurasian Journal of Biosciences, 14 (2), 4637-4644.

2. Schaalan, M. F., Ramadan, B. K., H. Abd Elwahab, A. (2018). Ameliorative effect of taurine-chloramine in azathioprine-induced testicular damage; a deeper insight into the mechanism of protection. BMC Complementary and Alternative Medicine, 18 (1). doi: http://doi.org/10.1186/s12906-018-2272-z

3. Panda, B. K., Umarje, S., Diwan, A. (2017). Azathioprine-Induced Pancytopenia and Septic Complications: A Probable Cause of Death. Journal of Pharmacy Practice, 31 (5), 510-513. doi: http://doi.org/10.1177/0897190017729521

4. Dubinsky, M. C. (2004). Azathioprine, 6-mercaptopurine in inflammatory bowel disease: Pharmacology, efficacy, and safety. Clinical Gastroenterology and Hepatology, 2 (9), 731-743. doi: http://doi.org/10.1016/s1542-3565(04)00344-1

5. Amouoghli Tabrizi, B., Mohajeri, D., Doostar, Y., Baradaran Alizade, S., Khodadadi, A., Farajzade, F. (2009). Biochemical and pathological study of protective effect of Vitamin A in Azathioprine-induced hepatotoxicity in Rat. KAUMS Journal (FEYZ), 13 (3), $180-187$.

6. Amin, A., Hamza, A. A. (2005). Hepatoprotective effects of Hibiscus, Rosmarinus and Salvia on azathioprine-induced toxicity in rats. Life Sciences, 77 (3), 266-278. doi: http://doi.org/10.1016/j.lfs.2004.09.048

7. Lee, A. U., Farrell, G. C. (2001). Mechanism of azathioprine-induced injury to hepatocytes: roles of glutathione depletion and mitochondrial injury. Journal of Hepatology, 35 (6), 756-764. doi: http://doi.org/10.1016/s0168-8278(01)00196-9 
8. Karawya, F. S., El-Nahas, A. F. (2006). The protective effect of vitamin C on Azathioprine induced seminiferous tubular structural changes and cytogenetic toxicity in albino rats. Cancer Therapy, 4, 125-134.

9. Godarzian, Z., Hosseini, E. (2018). Evaluating the Effect of Ginger Extract on Azathioprine-Induced Renal Failure in Mature Female Rats. Journal of Ardabil University of Medical Sciences, 18 (2), 215-229. doi: http://doi.org/10.29252/jarums.18.2.215

10. Mirazi, N., Karami, Z. (2016). The protective effect of hydroalcoholic extract from rhizome of Zingiber officinale L. on carbon tetrachloride-induced hepatic injury in male rat. KAUMS Journal (FEYZ), 20 (4), 297-305.

11. Aimbire, F., Penna, S. C., Rodrigues, M., Rodrigues, K. C., Lopes-Martins, R. A. B., Sertié, J. A. A. (2007). Effect of hydroalcoholic extract of Zingiber officinalis rhizomes on LPS-induced rat airway hyperreactivity and lung inflammation. Prostaglandins, Leukotrienes and Essential Fatty Acids, 77 (3-4), 129-138. doi: http://doi.org/10.1016/j.plefa.2007.08.008

12. Ali, B. H., Blunden, G., Tanira, M. O., Nemmar, A. (2008). Some phytochemical, pharmacological and toxicological properties of ginger (Zingiber officinale Roscoe): A review of recent research. Food and Chemical Toxicology, 46 (2), 409-420. doi: http://doi.org/10.1016/j.fct.2007.09.085

13. Mohan, G. K., Pallavi, E., Kumar, R., Ramesh, M., Venkatesh, S. (2007). Hepatoprotective activity of Ficus carica Linn leaf extract against carbon tetrachloride-induced hepatotoxicity in rats. DARU journal of Pharmaceutical Sciences, 15 (3), $162-166$.

14. Aryaeian, N. (2016). A review of the effect of Ginger in inflammation. Rahavard Salamat Journal, 2 (1), 52-64.

15. Maralla, S. (2013). Effect of ginger extract consumption on renal function during ethanol withdrawal induced-stress. International Journal of Innovative Research in Science, Engineering and Technology, 2 (11), 6412-6418.

16. Khoshvaghti, A., Mard Khoshnood, M. (2015). Investigation of Zingiber powder effects on liver, kidney and pancreas indexes in rat. Iranian Journal of Veterinary Clinical Sciences, 8 (1), 63-79.

17. Zekrizadeh, Z., Farokhy, F. (2014). The Effect of Hydroalcoholic Extract of Ginger (HEG) onHistological and Biochemical Parameters of Kidney in Epileptic Rats Treated with Lamotrigin. Qom University of Medical Sciences Journal, 8 (5), 54-62.

18. Rezaei, F., Abolahzadeh Fard, A., Tagizadeh Afshari, A. (2015). Ginger hydroalcoholic extract ameliorates the alcohol-induced kidney dysfunction in rat. Journal of Urmia Nursing and Midwifery Faculty, 13 (3), 246-252.

19. Srivastava, K. C., Mustafa, T. (1992). Ginger (Zingiber officinale) in rheumatism and musculoskeletal disorders. Medical Hypotheses, 39 (4), 342-348. doi: http://doi.org/10.1016/0306-9877(92)90059-1

20. Hosseini, S. E., Dalaeli, Z. (2016). The effect of lithium carbonate on the hypothalamic-pituitary-gonadal axis in adult female Wistar rats. Feyz, Journal of Kashan University of Medical Sciences, 19 (6), 450-456.

21. Mirzakhani, Z., Hosseini, S. E. (2017). Effects of chamomile hydroalcoholic extract (Matricaria chamomilla) on the aborted fetuses, serum sex hormones and ovarian follicles in adult female rats. Journal of Ardabil University of Medical Sciences, 17 (1), $22-31$.

22. Gad, S. B., Zaghloul, D. M. (2013). Beneficial effects of green tea extract on liver and kidney functions, ultrastructure, lipid profile and hematological parameters in aged male rats. Global Vet, 11 (2), 191-205.

23. Elelaimy, I. A., Elfiky, S. A., Hassan, A. M., Ibrahim, H. M., Elsayad, R. I. (2012). Genotoxicity of anticancer drug azathioprine (Imuran): role of omega-3 $(\omega-3)$ oil as protective agent. Journal of Applied Pharmaceutical Science, 2 (4), 14-23. doi: http://doi.org/10.7324/japs.2012.2404

24. Akinlolu, A., Akinola, O., Khobe, P., Obasi, K., Dada, O. (2014). Azathioprine and Methotrexate impaired the morphology and functions of the testes in adult wistar rats. Journal of Morphological Sciences, 31 (2), 75-81. doi: http://doi.org/10.4322/jms.057513

25. Johari H, Sharifi E, Delirnasab F, Hemayatkhah V, Kargar H, Nikpoor M. The effect of hydroalcoholic extracts of Ginger on lead detoxification of kidney in the immature wistar rats. J Rafsanjan Univ Med Sci. 2013;12:417-24.

26. Hosseini, A., Mirazi, N. (2014). Acute administration of ginger (Zingiber officinale rhizomes) extract on timed intravenous pentylenetetrazol infusion seizure model in mice. Epilepsy Research, 108 (3), 411-419. doi: http://doi.org/10.1016/j.eplepsyres.2014.01.008

27. Moalem, S. A., Tafazoli, M., Niapour, M. (2003). Evaluation of teratogenic effects of zingiber officinale in mice. Iranian Journal of Basic Medical Sciences, 6 (1), 43-52.

28. Rahman, S., Salehin, F., Iqbal, A. (2012). Retraction Note: In Vitro antioxidant and anticancer activity of young Zingiber officinale against human breast carcinoma cell lines. BMC Complementary and Alternative Medicine, 12 (1). doi: http://doi.org/10.1186/14726882-12-206

29. Abo-Salem, O. M., Abd-Ellah, M. F., Ghonaim, M. M. (2011). Hepatoprotective activity of quercetin against acrylonitrileinduced hepatotoxicity in rats. Journal of Biochemical and Molecular Toxicology, 25 (6), 386-392. doi: http://doi.org/10.1002/jbt.20406

30. Abarikwu, S. (2014). Protective effect of quercetin on atrazine-induced oxidative stress in the Liver, Kidney, Brain, and Heart of adult wistar rats. Toxicology International, 21 (2), 148. doi: http://doi.org/10.4103/0971-6580.139794

31. Zhang, Y., Gao, Z., Liu, J., Xu, Z. (2011). Protective effects of baicalin and quercetin on an iron-overloaded mouse: comparison of liver, kidney and heart tissues. Natural Product Research, 25 (12), 1150-1160. doi: http://doi.org/10.1080/14786419.2010.495070

32. Salah, S. H., Abdouh, S., Hodaf, B., Abdel, R. E. A. (2012). Effect of Zingiber Officinale on paracetamol-induced genotoxicity in male rats. Journal of Medicinal Plants Research, 6 (41), 5425-5434. doi: http://doi.org/10.5897/jmpr12.218

Received date 23.06.2021

Accepted date 26.08.2021

Published date 31.08.2021

Saja Majeed Shareef*, Department of Pharmacy, Al-Esraa University College, Baghdad, Iraq, 10071

Raghad Abdulsalam Khaleel, Department of Pharmacology, College of Medicine, Al Iraqia University, Baghdad, Iraq, 10071

Zinah Essam Hameed, Department of Pharmacy, Al-Esraa University College, Baghdad, Iraq, 10071

Khulood Majid Alsaraf, Department of Pharmacy, Al-Esraa University College, Baghdad, Iraq, 10071

*Corresponding author: Saja Majeed Shareef, e-mail: saja.majeed@esraa.edu.iq 